\title{
HUBUNGAN TINGKAT STRES AKADEMIK DENGAN SIKLUS MESNTRUASI PADA MAHASISWI PROGRAM STUDI D3 FARMASI TINGKAT 1 (SATU) FAKULTAS ILMU KESEHATAN UNIVERSITAS MUHAMMADIYAH MATARAM
}

\author{
*Ika Nurmala Sari, Alvi Kusuma Wardani, Abdul Rahman Wahid \\ Program Studi D3 Farmasi, Fakultas IImu Kesehatan, Universitas Muhammadiyah Mataram, ${ }^{*}$ Ikanurmalasari98@gmail.com
}

\section{INFO ARTIKEL}

Riwayat Artikel:

Diterima: 03-09-2019

Disetujui: 23-01-2020

\section{Kata Kunci:}

Mahasiswi

Stres

Siklus Menstruasi

\section{A. LATAR BELAKANG}

Kesehatan reproduksi merupakan bagian paling penting dalam program kesehatan, kesehatan reproduksi mempunyai pengaruh terhadap aspek kehidupan yaitu

\begin{abstract}
Abstrak: Mahasiswa sebagai bagian dari sekelompok individu yang merupakan bagian dari sasaran integrasi akademik, menjadi kelompok yang rentan untuk mengalami ketidakseimbangan homeostatis akibat stres yang berasal dari kehidupan akademik. Peningkatan kejadian stress akademik akan meningkatkan kemampuan akademik yang mempengaruhi index perestasi dan beratnya stress dapat menyebabkan seseorang berperilaku negatif. Tujuan penelitian ini adalah untuk mengetahui adanya hubungan tingkat stress akademik terhadap siklus menstruasi pada mahasiswi Prodi D3 Farmasi tingkat 1 (satu) Fakultas Ilmu Kesehatan Universitas Muhammadiyah Mataram. Metode yang digunakan adalah metode penelitian korelatif dengan uji chi - square. Digunakan teknik purposive sampling hingga diperoleh sampel sebanyak 35 orang. Instrumen penelitian merupakan kuesioner yang didasarkan atas variabel penelitian, yakni tingkat stress dan siklus menstruasi. Hasil analisa univariat menunjukkan bahwa 10 orang $(28,4 \%)$ memiliki tingkat stres normal, 15 orang $(42,4 \%)$ memiliki stress tingkat ringan, 8 orang $(22,8 \%)$ memiliki stress tingkat sedang, dan 2 orang $(5,7 \%)$ memiliki stress tingkat berat; 5 orang $(14,2 \%)$ mengalami polimenorea, 24 orang (68,5\%) memiliki siklus menstruasi normal, 6 orang $(17,1 \%)$ mengalami oligomenrea. Hasil analisa bivariat pada SPSS dengan menggunakan ujichi square menunjukkan nilai korelasi korelatif ( $r$ ) sebesar 0,760 dan nilai $p$ sebesar $0,000(p<$ $0,05)$ yang berarti ada hubungan signifikan antara tingkat stress dengan siklus menstruasi mahasiswi D3 Farmasi Tingkat 1 (satu) Fakultas Ilmu Kesehatan Universitas Muhammadiyah Mataram. Kesimpulan berdsarkan hasilpenelitian pada mahasiswi dapat disimpulkan bahwa ada hubungan antara tingkat stress dengan siklus menstruasi mahasiswi D3 Farmasi Tingkat 1 (satu) Universitas Muhammadiyah Mataram $(p=0,000 ; p=<0,005$ dengan besar korelasi $r=0,760)$
\end{abstract}

\begin{abstract}
Student as part of a group of individuals who are part of the target of academic integration, being vulnerable to experiencing homeostatic imbalances due to stress from academic life. The increase in academic stress events will increase academic abilities that affect achievement indexes and stress severity causes a person to behave negatively. The purpose of this study was to determine the correlation between academic stress levels on the menstrual cycle in pharmacist D3 level 1 (one) fakulty the health science of Muhamadiyah University of Mataram. The method used is the correlation research method of the chi-square test. Used purposive sampling technique to get a sample of 35 people. Research instruments are questionnaires based on by research variables, namely cycle stress and menstrual levels. Univariate analysis revealed that 10 people (28.4\%) had normal stress levels, 15 people (4.24\%) had mild stress levels, 8 people (22.8\%) had moderate stress levels, and 2 people $(5,7 \%$ had severe stress, 5 people had (14.2\%) experienced polimenorea, 24 people (68.5\%) had normal menstrual cycles, 6 people (17.1\%) had oligomenorea. The bivariate analysis on the SPSS using the chi-square test showed that the value of collerative correlation (r) was 0.760 and the value $(p)$ was large $0.000(<p 0.05)$ which meant there was a significant relationship between the stress level and the pharmaceutical D3 cycle level 1 (One) fakulty health science Muhamdiyah University of Mataram. The conclusion based on the results of research on female students can be concluded that there is a relationship between stress levels with menstrual cycles D3 Pharmacy Level 1 (one) Muhammadiyah University of Mataram ( $P=0,000 ; p<0,005$ with a large correlation $r=0,760)$
\end{abstract}

sejak dalam kandungan sampai ia berusia lanjut. Beberapa penyakit ginekologi dan gangguan kesehatan reproduksi merupakan masalah yang serius seperti gangguan kemandulan, keputihan, kanker rahim, menstruasi dan lain sebagainya (Wiknjosastro, 2007). 
Menstruasi sebagai proses alamiah yang akan terjadi pada setiap remaja, dimana terjadinya proses pengeluaran darah yang menandakan bahwa organ kandungan telah berfungsi dengan matang (Kusmiran, 2011).

Menstruasi adalah siklus discharge fisiologik darah dan jaringan mukosa melalui vagina dari uterus yang tidak hamil di bawah kendali hormonal dan berulang tanpa adanya kehamilan selama periode reproduktif (Dorland, 2000). Menstruasi biasanya berlangsung selama lima sampai tujuh hari dan rata - rata darah yang keluar adalah 35 - $50 \mathrm{ml}$ tanpa bekuan darah (Wiknjosastro, 2012).

Siklus menstruasi idealnya teratur setiap bulan dengan rentang waktu antara 21 - 35 hari setiap kali periode menstruasi. Siklus menstruasi normal secara fisiologis menggambarkan organ reproduksi cenderung sehat dan tidak bermasalah. Sistem hormonalnya baik, ditunjukkan dengan sle telur yang terus diproduksi dan siklus menstruasi teratur sehingga dengan siklus menstruasi yang normal, seorang wanita akan lebih mudah mendaptkan kehamilan, menata rutinitas, dan menghitung masa subur (Hestiantoro, 2007).

Gangguan mentruasi merupakan masalah yang cukup banyak dihadapi oleh wanita, terutama pada usia remaja. Gangguan ini mungkin berkaitan dengan lamanya siklus menstruasi haid, atau jumlah lamanya menstruasi (Winkjosastro, 2005). Jumlah gangguan menstruasi paling umum terjadi pada awal dan akhir masa reproduktif, yaitu di bawah usia 19 tahun dan di atas 39 tahun (Nita, 2005). Gangguan menstruasi sering merupakan sumber kecemasan bagi wanita. Gangguan menstruasi yang umum terjadi adalah amenorrhea, perdarahan uterus abnormal, disminorea, dan sindrom premenstrual (Owen, 2005). (Cakir et al, 2007) dalam penelitiannya menemukan bahwa disminorea merupakan gangguan menstruasi dengan prevalensi terbesar $(89,5 \%)$, diikuti ketidak teraturan mentsruasi (31,2\%), serta pemanjangan durasi menstruasi $(5,3 \%)$. (Benias et al, 2006) mendapatkan prevalensi amenorea primer sebanyak 5,3\%, amenorea sekunder $18,4 \%$, oligomenorea 50\%, polimenorea $10,5 \%$ dengan ganggaun campuran sebanyak 15,8\%. Berdasrkan penelitian yang dilakukan oleh (Anamika et al, 2008) terhadap mahasiswa didapatkan bahwa sindrom pramenstruasi dan dismenorea merupakan keluhan yang dirasakan paling mengganggu. Efek gangguan menstruasi yang dilaporkan anatra lain waktu istirahat memanjang, menurunnya kemampuan belajar dan stres.

Stres adalah reaksi/respon tubuh terhadap stressor psikososial (tekanan mental/beban kehidupan). Dewasa ini stres digunakan secara berganti untuk menjelaskan sebagai stimulus dengan intensitas berlebihan yang tidak disukai berupa respon fisiologis, perilaku dan subjekrif terhadap stresor, konteks yang menjabatani pertemuan antara individu dengan stimulus yang membuat stres, semua sebagai suatu sistem. Dalam pengaruhnya terhadap siklus menstruasi, stres melibatkan sistem yang besar peranannya dalam reproduksi pada wanita (Sriati, 2007). Carveth (Misrah \& McKean, 2000) menjelaskan bahwa stres akademik atau academic stressor bersumber dari proses belajar mengajar yang mempengaruhi proses berfikir, fisik, emosi dan perilaku yang ditimbulkan. (Hicks dan Heastie, 2008) juga menyatakan bahwa mahasiswa sangat rentan mengalami stres akademik diakibatkan oleh tuntutan untuk berfikir lebih tinggi dan ktitis, kehidupan yang mandiri, serta berperan dalam kehidupan sosial masyarakat.

Mahasiswa sebagai bagian dari kelompok individu yang merupakan bagian dari sasaran integrasi akademik, menjadi kelompok yang rentan untuk mengalami ketidakseimbangan homeostatis akibat stres yang berasal dari kehiduapn akademik. Tanggung jawab dan tuntutan kehidupan akademik pada mahasiswi dapat menjadi bagian stres yang bisa dialami mahasiswi. Mahasiswi tergolong usia remaja akhir dengan kisaran usia 18 - 20 tahun (Wong's 7 Hockenberry, 2007). Studi literatur yang mengungkapkan tingkat stres pada remaja cenderung tinggi. Jumlah mahasiswi yang mengalami stres akademik meingkat setiap semesternya. Stres yang paling umum dialami oleh mahasiswi merupakan stres akademik. Stres akademik diartikan sebagai suatu keadaan individu yang mengalami tekanan hasil presepsi dan penilaian tentang stressor akademik, yang berhubungan dengan ilmu penegtahuan dan pendidikan di perguruan tinggi (Govvarest \& Gregoire, 2004). Stres akademik yang dialami oleh mahasiswi seperti tugas perkuliahan, laporan praktik, dan lain- lainya.

\section{B. METODE PENELITIAN}

Penelitian ini merupakan penelitian yang bersifat Observasional Analitik dengan rancangan penelitian cross-sectional. Tempat penelitian ini dilakukan di Fakultas Kesehatan Universitas Muhammadiyah Mataram. Pada tanggal 24 - 27 Juni 2019. Populasi dalam penelitian ini adalah mahasiswi D3 Farmasi Tingkat 1 (satu) Fakultas Ilmu Kesehatan Universitas Muhammadiyah Mataram yang berjumlah 53 mahasiswi, dengan teknik pengambilan sampel yaitu non probability sampling dengan jenis purposive sampling. Dengan kriteria inklusi yang telah ditetapkan.

Instrument pada penelitian ini adalah kuesioner Perceived Of Stress Scale (PSS) dengan menggunakn kuesioner yang terdiri dari 34 item pertanyaan yag telah diujivaliditasnya. Dengan kategori tingkat stres normal 0-38, ringan $39-57$, sedang $58-76$, berat $77-96$, dan sangat berat $>97$.

Analisis univariat digunakan untuk membandingkan karakteristik antara dua variabel, sedangkan analisis bivariate digunakan untuk membandingkan karakteristik antara dua variabel dan menjelaskan hubungan antara dua variabel yaitu variabel dependen dengan variabel independen. 


\section{HASIL DAN PEMBAHASAN}

\section{Distribusi Karakteristik Responden}

TABEL1.

Distribusi Responden Penelitian

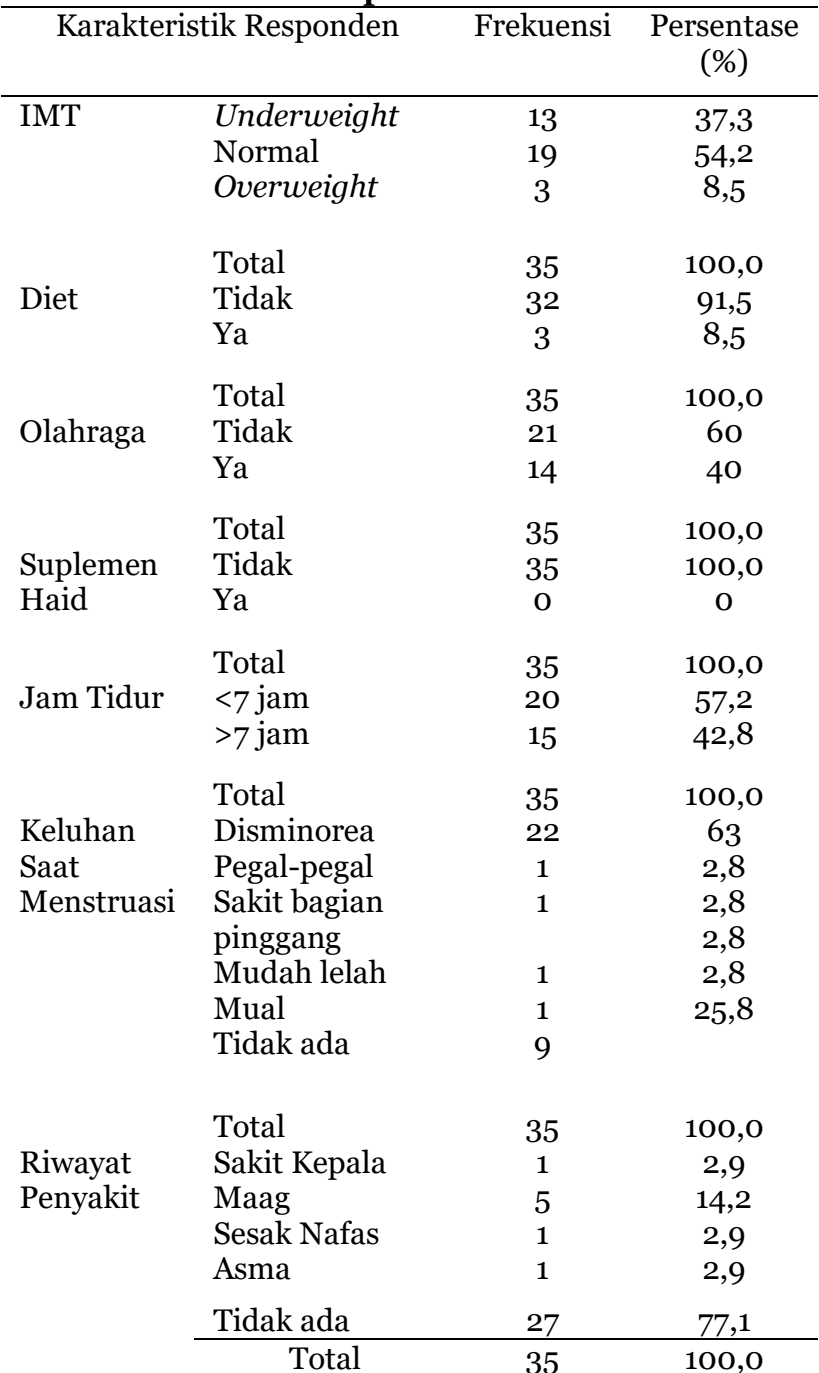

Sumber: Data Primer, 2019

Berdasarkan tabel 1 menunjukkan jumlah responden terbanyak memiliki IMT normal (19 orang), sedangkan sisanya memiliki IMT underweight (13 orang) dan overweight (3 orang). Berdasarkan riwayat melakukan diet selama 3 bulan terakhir, jumlah responden terbanyak tidak melakukan diet (32 orang), sedangkan sisanya melakukan diet (3 orang). Dari segi kebiasaan sering berolahraga, jumlah responden terbanyak tidak sering berolahraga (21 orang), sedangkan sisanya sering berolahraga (14 orang). Berdasarkan kebiasaan mengonsumsi suplemen pelancar haid, semua responden (35 orang) tidak mengonsumsi suplemen pelancar haid. Dari segi rata - rata jumlah jam tidur dalam sehari, jumlah responden terbanyak memiliki rata-rata jam tidur $<7$ jam (20 orang) dan yang paling sedikit memiliki rata-rata jam tidur $>7$ jam (15 orang). Berdasarkan keluhan yang muncul saat menstruasi, jumlah responden terbanyak memiliki keluhan disminorea (22 orang) dan yang paling sedikit memliki keluhan pegal-pegal, sakit pada bagian pinggang, mudah lelah dan mual (1 orang). Dari segi riwayat penyakit, jumlah responden terbanyak tidak memiliki riwayat penyakit (27 orang) Penelitian ini sesuai dengan penelitian Nahliyatul Ulum (2016) di Program Studi Fisioterapi Fakultas Kedokteran Universitas Hasanuddin yang menyatakan jumlah responden terbanyak memiliki IMT normal (47 orang), sedangkan sisanya memiliki IMT underweight (17orang) dan overweight (9 orang). Berdasarkan riwayat melakukan dietselama 3 bulan terakhir, jumlah responden terbanyak tidak melakukan diet (61 orang), sedangkan sisanya melakukan diet (12 orang). Dari segi kebiasaan sering berolahraga, jumlah responden terbanyak tidak sering berolahraga (53 orang), sedangkan sisanya sering berolahraga (14 orang). Berdasarkan kebiasaan mengonsumsi suplemen pelancar haid, semua responden (73 orang) tidak mengonsumsi suplemen pelancar haid. Dari segi rata-rata jumlah jam tidur dalam sehari, jumlah responden terbanyak memiliki rata-rata jam tidur $<7$ jam (38 orang) dan yang paling sedikit memiliki rata-rata jam tidur $>7$ jam (35 orang). Berdasarkan keluhan yangmuncul saat menstruasi, jumlah responden terbanyak memiliki keluhan dismenorea (49 orang) dan yang paling sedikit memiliki keluhan dehidrasi dan diare (1 orang). Dari segi riwayat penyakit, jumlah responden terbanyak tidak memiliki riwayat penyakit (52 orang).

Indeks massa tubuh (IMT) merupakan salah satu ukuran untuk memprediksi persentase lemak di dalam tubuh manusia. Lemak merupakan salah satu senyawa di dalam tubuh yang mempengaruhi proses pembentukan hormon estrogen, dan salah satu faktor dominan penyebab gangguan menstruasi adalah hormone estrogen. Memiliki IMT tinggi atau rendah dapat menyebabkan gangguan menstruasi diantaranya tidak ada menstruasi atau amenorea, menstruasi tidak teratur dan nyeri pada saat menstruasi (Retissu, et al., 2010).

Lemak dan serat merupakan salah satu zat gizi yang dapat mempengaruhi siklus menstruasi. Lemak dapat membantu untuk mengontrol siklus menstruasi, yaitu dengan meningkatkan produksi estrogen di dalam tubuh dan mengatur siklus menstruasi. Diet rendah lemak berhubungan dengan siklus menstruasi yang dating terlambat, sedanngkan diet tinggi lemak akan berpengaruh terhadap hormon steroid yang akan memacu datangnya menstruasi lebih cepat. Sedangkan wanita yang mengkonsumsi serat yang disarankan dalam diet memiliki estrogen yang lebih rendah dan ovulasi yang lebih teratur dibandingkan dengan wanita yang kurang maupun lebih dalam mengkonsumsi serat (Kusmiran, 2012 dan Paath et al, 2005). 
Olahraga berlebihan dapat menyebabkan terjadinya disfungsi hipotalamus yang menyebabkan gangguan pada sekresi GnrH. Hal tersebut menyebabkan terjadinya menarche (menstruasi pertama) yang tertunda dan gangguan siklus mesntruasi. Faktor penyebab supresi $\mathrm{GnrH}$ atlet wanita adalah penggunaan energi berlebihan yang melebihi pemasukan energi pada atlit. Faktor kekurangan nutrisi merupakan faktor penting penyebab keadaan hipoestrogen pada atlit wanita.

Berdasarkan riwayat mengonsumsi suplemen haid tidak ada hubungannya dengan siklus menstruasi. Hal ini menunjukkan bahwa siklus menstruasi responden tidak dipengaruhi oleh suplemen pelancar haid sesuai dengan Kusmiran (2011) yang menyatakan bahwa konsumsi obat - obatan tertentu akan menyebabkan terjadinya perubahan siklus menstruasi.

Dari segi rata - rata jumlah tidur tidak ada hubungannya dengan siklus menstruasi, hal ini bisa disebabkan oleh banyaknya aktifitas yang dilakukan oleh seseorang. Menurut Robothom (2011), saat seseorang mencapai tahap dewasa, mereka cenderung memerlukan waktu tidur $7-8$ jam per hari. Individu dengan waktu tidur yang kurang akan mempengaruhi kesehatan mentalnya serta dapat mengalami depresi.

Dari segi keluhan yang muncul saat menstruasi salah satunya disminorea yang mempunyai pengaruh dengan siklus menstruasi. Gangguan siklus mesntruasi merupakan masalah yang kerap dikeluhkan oleh remaja, selai itu keluhan lain yang dikeluhkan remaja juga ialah disminorea atau nyeri haid. Nyeri haid atau disminorea merupakan keluhan ginekologis akibat ketidakseimbangan hormon progesteron sehingga mengakibatkan timbulnya rasa nyeri yang dialami wanita.Angka kejadian disminorea di dunia sangat besar, rata - rata lebih dari 50\% perempuan di setiap Negara mengalami nyeri menstruasi. Di Amerika angka presentasenya sekitar $60 \%$ dan di Swedia sekitar 70\% sementara di Indonesia angkanya di perkirakan $55 \%$ perempuan usia produktif yang tersiksa oleh nyeri menstruasi (Gustina, 2015).

\section{Distribusi Responden Berdasarkan Karakteristik dan Siklus Menstruasi \\ TABEL 2.}

Distribusi Responden Berdasarkan

Karakteristik dan Sijlus Menstruasi

\begin{tabular}{llllll}
\hline \multirow{2}{*}{ Karakteristik Responden } & \multicolumn{4}{c}{ Siklus Menstruasi } & \multirow{2}{*}{ Total } \\
\cline { 3 - 5 } & $\begin{array}{c}\text { Polim } \\
\text { enorea }\end{array}$ & $\begin{array}{c}\text { Nor } \\
\text { mal }\end{array}$ & $\begin{array}{c}\text { Oligomen } \\
\text { orea }\end{array}$ & \\
\hline IMT & Underweight & 1 & 10 & 1 & 12 \\
& Normal & 3 & 12 & 4 & 19 \\
& Overweight & 1 & 2 & 1 & 4 \\
& Total & $\mathbf{5}$ & $\mathbf{2 4}$ & $\mathbf{6}$ & $\mathbf{2 9}$ \\
Diet & Tidak & 5 & 21 & 3 & 32 \\
& Ya & O & 3 & 3 & 6 \\
& Total & $\mathbf{5}$ & $\mathbf{2 4}$ & $\mathbf{6}$ & $\mathbf{3 5}$
\end{tabular}

\begin{tabular}{|c|c|c|c|c|c|}
\hline \multirow[t]{3}{*}{ Olahraga } & Tidak & 5 & 12 & 4 & 21 \\
\hline & Ya & $\mathrm{O}$ & 12 & 2 & 14 \\
\hline & Total & 5 & 24 & 6 & 35 \\
\hline \multirow{3}{*}{$\begin{array}{l}\text { Suplemen } \\
\text { Haid }\end{array}$} & Tidak & 5 & 24 & 6 & 35 \\
\hline & $\mathrm{Ya}$ & $\mathrm{O}$ & $\mathrm{O}$ & O & $\mathrm{O}$ \\
\hline & Total & 5 & 24 & 6 & 35 \\
\hline \multirow[t]{3}{*}{ Jam Tidur } & $<7$ jam & 3 & 14 & 3 & 20 \\
\hline & $>7$ jam & 2 & 10 & 3 & 15 \\
\hline & Total & 5 & 24 & 6 & 35 \\
\hline \multirow{7}{*}{$\begin{array}{l}\text { Keluhan } \\
\text { Saat } \\
\text { Menstruasi }\end{array}$} & Disminorea & 3 & 15 & 4 & 22 \\
\hline & Peoal-neoal & 0 & 1 & 0 & 1 \\
\hline & $\begin{array}{l}\text { Sakit bagian } \\
\text { pinggang }\end{array}$ & o & 1 & o & 1 \\
\hline & Mudah lelah & $\mathrm{o}$ & 1 & $\mathrm{O}$ & 1 \\
\hline & Mual & o & 1 & o & 1 \\
\hline & Tidak ada & 2 & 5 & 2 & 9 \\
\hline & Total & 5 & 24 & 6 & 35 \\
\hline \multirow{6}{*}{$\begin{array}{l}\text { Riwayat } \\
\text { Penyakit }\end{array}$} & Sakit Kepala & $\mathrm{O}$ & 1 & $\mathrm{O}$ & 1 \\
\hline & Maag & 1 & 5 & 1 & 7 \\
\hline & Sesak nafas & $\mathrm{O}$ & 1 & $\mathrm{O}$ & 1 \\
\hline & Asma & $\mathrm{O}$ & 1 & $\mathrm{O}$ & 1 \\
\hline & Tidak ada & 4 & 18 & 5 & 27 \\
\hline & Total & 5 & 24 & 6 & 35 \\
\hline
\end{tabular}

Sumber: Data Primer, 2019

Berdasarkan tabel 2, ada 5 responden yang mengalami polimenorea, 24 responden mengalami siklus menstruasi normal, dan sisanya 6 responden mengalami oligomenorea. Berdasarkan karakteristiknya, responden terbanyak yang mengalimi polimenorea yakni memiliki IMT normal (3 orang), tidak melakukan diet (5 orang), tidak sering mengonsumsi suplemen pelancar haid (5 orang), tidak sering berolahraga (5orang), memiliki rata-rata $<7$ jam tidur sehari (3 orang), memiliki keluhan disminorea saat menstruasi (3 orang), dan tidak memiliki riwayat penyakit (4 orang). Responden terbanyak yang mengalami oligomenorea yang memiliki IMT normal (4 orang), tidak melakukan diet (6 orang), tidak mengonsumsi suplemen pelancar haid (4 orang), tidak sering berolahrga ( 6 orang), memiliki rata - rata $<7$ jam tidur sehari dan $>7$ jam memiliki jumlah yang sama (3 orang), memiliki keluhan disminore saat menstruasi (4 orang), dan tidak memilik riwayat penyakit (5 orang).

Indeks Massa Tubuh (IMT) adalah pengukuran yang digunakan untuk menilai apakah seseorang memiliki berat badan normal, kelebihan atau kekurangan terkaitt inggi badan seseorang (CDC, 2011).Cara menentukan IMT yaitu dengan membagi nilai berat badan dengan nilai tinggi badan yang dipangkatkan. Hasil nilai IMT yang didapatkan makna $<18,50$ (underweight); 18,50-24,99 (normal); 25,00 (overweight) (Sugondo, 2007).

Dari segi Indeks Massa Tubuh dan dihubungkan dengan siklus menstruasi responden, terdapat 1 responden yang memiliki IMT kategori underweight dengan siklus menstruasi polimenorea, hal ini sesuai dengan penelitian Sifra, dkk (2012), dimana sebagian besar responden yang memiliki IMT underweight 
menunjukkan adanya gangguan siklus menstruasi polimenorea. Terdapat 10 orang responden yang memiliki IMT kategori normal dengan siklus menstruasi normal, hal ini sesuai dengan penelitian Harahap (2013) yang membuktikan bahwa ada hubungan antara IMT dengan siklus menstruasi. Terdapat pula 1 responden yang memiliki IMT kategori overweight dengan siklus menstruasi oligemonerea, hal ini sesuai dengan penelitian Rakhmawati, dkk (2013) dimana obesitas merupakan faktor yang dapat menyebabkan terjadinya gangguan siklus menstruasi.

Dalam kamus Gizi Pelengkap Kesehatan Keluarga (2009) keluaran Persatuan AhliGizi Indonesia (Parsegi), diet memiliki arti sebagai pengaturan pola dan konsumsi makanan serta minuman yang dilarang, dibatasi jumlahnya, dimodifikasi, atau diperbolehkan dengan jumlah tertentu untuk tujuan terapi penyakit yang diderita, kesehatan, atau penurunan berat badan.

Dari segiriwayat melakukan diet selama 3 bulan terakhir, terdapat 32 responden yang tidak melakukan diet selama 3 bulan terakhir serta terdapat 3 responden yang melakukan diet selama 3 bulan terakhir. Jika dihubungkan dengan siklus menstruasinya, responden yang mengalami polimenorea tidak ada yang melakukan diet, sedangkandari 6 responden yang mengalami oligomenorea, terdapat 3 responden yang melakukan diet selama 3 bulan terakhir. Hal ini sesuai dengan pendapat Krummel dalam Kusmiran (2011) yang mengatakan bahwa diet rendah lemak akan menyebabkan panjang siklus menstruasi meningkat.

Berdasarkan arti kata dalam undang - undang ketentuan pokok olahraga tahun 1997 pasal 1, yang dimaksud dengan olahraga adalah semua kegiatan jasmani yang dilandasi semangat untuk melelahkan diri sendiri maupun orang lain, yang dilandaskan secara kewenangan sehingga olahraga merupakan saran menuju peningkatan kualitas dan ekspresi hidup yang lebih luhur bersama sesama manusia.

Dari segi kebiasaan berolahraga, terdapat 21 responden yang tidak sering berolahraga serta 14 responden yang sering berolahrga. Jika dihubungkan dengan siklus menstruasinya, responden yang mengalami polimenorea tidak ada yang sering berolahraga. Sedangkan dari dari 6 responden yang mengalami oligemenorea, terdapat 2 responden yang sering berolahraga. Hal ini sesuai dengan hasil penelitian Asmarani (2010), dimana pada atlit yang siklus menstruasinya teratur. Olahraga yang dimaksud yang dapat mempengaruhi siklus mesntruasi adalah olahraga yang berlebihan. Olahraga berlebihan dapat menyebabkan terjadinya disfungsi hipotalamus yang menyebabkan gangguan sekresi GnRH (Asmarani, 2010).
Dari segi kebiasaan mengonsumsi suplemen pelancar haid, tidak ada responden yang mengonsumsi suplemen pelancar haid. Hal ini menunjukkan bahwa siklus menstruasi responden tidak dipengaruhi oleh suplemen pelancar haid sesuai dengan Kusmiran (2011) yang menyatakan bahwa konsumsi obat - obatan tertentu akan menyebabkan terjadinya perubahan siklus menstruasi.

Tidur adalah periode istirahat untuk tubuh dan pikiran, yang selama massa ini kemauan dan kesadaran ditangguhkan sebagai atau seluruhnya dan fungsi - fungsi tubuh sebagian dihentikan. Selain itu tidur juga telah dideskripsikan sebagai status tingkah laku yang ditandai dengan posisi tak bergerak yang khas dan sensitivitas reversibel yang menurun, tapi siaga terhadap rangsangan dari luar (Dorland, 2002).

Dari segi rata - rata jumlah jam tidur dalam sehari, terdapat 20 responden yang memiliki rata rata $<7$ jam tidur sehari, hal ini bisa disebabkan oleh banyaknya aktifitas yang dilakukan oleh responden mengingat seluruh responden termasuk dalam kategori usia produktif. Menurut Robotham (2011), saat seseorang mencapai tahap dewasa, mereka cenderung memerlukan waktu tidur $7-8$ jam per hari. Individu dengan waktu tidur yang kurang akan mempengaruhi kesehatan mentalnya serta dapat mengalami depresi.

Dari segi keluhan yang muncul saat menstruasi, terdapat 9 responden yang tidak memiliki keluhan, 22 responden yang memiliki keluhan dismenorea saat menstruasi, sedangkan pada keluhan pegalpegal, sakit bagian pinggang, mudah lelah, dan mual, terdapat masing - masing 1 responden yang mengalami keluhan tersebut. Hasil penelitian Sari, dkk (2015) membuktikan bahwa ada hubungan yang bermakna antara stres dengan kejadian dismenorea.

Dari segi riwayat penyakit, terdapat 27 responden yang tidak memiliki riwayat penyakit, 5 responden yang memiliki riwayat penyakit maag, responden dengan riwayat penyakit sakit kepala, asma,dan sesaknafas terdapat masing - masing 1 responden.

\section{Hubungan Tingkat Stres dengan Siklus Menstruasi}

TABEL3.

Hubungan Tingkat Stres dengan Siklus Menstruasi

\begin{tabular}{|c|c|c|c|c|c|c|}
\hline \multirow[b]{2}{*}{$\begin{array}{l}\text { Tingkat } \\
\text { Stres }\end{array}$} & \multicolumn{3}{|c|}{ Siklus Menstruasi } & \multirow[b]{2}{*}{$\begin{array}{l}\text { Total } \\
\text { (\%) }\end{array}$} & \multirow[b]{2}{*}{$\mathrm{P}$} & \multirow[b]{2}{*}{$\mathrm{r}$} \\
\hline & $\begin{array}{l}\text { Polim } \\
\text { enore } \\
\text { a } \\
\text { (\%) }\end{array}$ & $\begin{array}{l}\text { Nor } \\
\text { mal } \\
(\%)\end{array}$ & $\begin{array}{l}\text { Oligo } \\
\text { men } \\
\text { orea } \\
(\%)\end{array}$ & & & \\
\hline Normal & $\begin{array}{c}5 \\
(14,2)\end{array}$ & $\begin{array}{c}5 \\
(14,2)\end{array}$ & $\begin{array}{c}0 \\
(0)\end{array}$ & $\begin{array}{c}10 \\
(28,4)\end{array}$ & & \\
\hline Ringan & $\begin{array}{l}0 \\
\text { (o) }\end{array}$ & $\begin{array}{c}15 \\
(42,8)\end{array}$ & $\begin{array}{c}0 \\
(40)\end{array}$ & $\begin{array}{c}15 \\
(42,8)\end{array}$ & $\begin{array}{l}0,0 \\
0,0\end{array}$ & $\begin{array}{c}0,76 \\
0\end{array}$ \\
\hline Sedang & $\begin{array}{c}0 \\
\text { (o) }\end{array}$ & $\begin{array}{c}4 \\
(11,4)\end{array}$ & $\begin{array}{c}4 \\
(11,4)\end{array}$ & $\begin{array}{c}8 \\
(22,8)\end{array}$ & & \\
\hline Berat & $\begin{array}{c}0 \\
(0)\end{array}$ & $\begin{array}{l}0 \\
(0)\end{array}$ & $\begin{array}{c}2 \\
(5,7)\end{array}$ & $\begin{array}{c}2 \\
(5,7)\end{array}$ & & \\
\hline Sangat & $\mathrm{o}$ & 0 & 0 & 0 & & \\
\hline
\end{tabular}




\begin{tabular}{lcccc} 
Berat & $(0)$ & $(0)$ & $(0)$ & $(0)$ \\
\hline Total & 5 & 24 & 6 & 35 \\
& $(14,2)$ & $(68,7)$ & $(17,1)$ & $(100)$ \\
\hline
\end{tabular}

Dari Tabel 3 menunjukkan hasil analisis data dengan menggunakan uji chi-square, menunjukkan bahwa diperoleh nilai signifikan antara tingkat stres dengan siklus menstruasi responden sebesar $\mathrm{p}=0,000$ $(\mathrm{p}=<0,05)$. Hal ini menunjukkan bahwa ada hubungan antara tingkat stres akademik dengan siklus menstruasi. Sedangkan besarnya nilai korelasi nilai $r=$ 0,760 menunjukkan adanya kekuatan korelasi yang sangat kuat antara tingkat stres dengan siklus menstruasi responden. Nilai koefesien korelasi yang bertanda positif menunjukkan mempunyai hubungan yang searah. Hal ini sesuai dengan teori (Sarwono, 2006) yang menyatakan korelasi yang sangat kuat berkisar >0,75-0,99. Nasution (2007) mengatakan bahwa stres adalah keadaan yang disebabkan oleh adanya tuntutan internal maupun eksternal yang dapat membahayakan, tidak terkendali atau melebihi kemampuan individu sehingga individu akan bereaksi dan melakukan usaha - usaha penyusaian diri terhadap situasi tersebut. Hasil penelitian ini menjelaskan bahwa distribusi stres terbanyak mahasiswi D3 Farmasi Tingkat 1 (Satu) Universitas Muhammadiyah Mataram yaitu stres ringan sebanyak 15 orang $(42,8 \%)$. Hal ini sesuai dengan pendapat Sudrajat (2008), bahwa belajar di perguruan tinggi merupakan suatu pekerjaan yang berat yang menuntut upaya yang tidak sedikit. Banyak kegiatan belajar yang harus dimiliki oleh mahasiswa, seperti pemilihan cara belajar, pengaturan cara belajar, pengaturan waktu belajar, memilih mata kuliah yang cocok, memplajari buku - buku yang pada umumnya ditulis dalam bahasa asing, mengkaji bermacam teori dan penelitian, membuat laporan tertulis dan sebagainya.

Berdasarkan hasil kuesioner tingkat stres yang diberikan kepada mahasiswi D3 Farmasi Tingak 1 (Satu) Universitas Muhammadiyah Mataram penyebab stres terbanyak berasal dari perasaan sehari - hari mahasiswi. Seperti yang kita ketahui bahwa responden penelitian ini adalah perempuan. Perempuan cenderung lebih banyak dikontrol oleh perasaan mereka dalam menghadapi masalah.

Fitria (2007) mengungkapkan bahwa menstruasi adalah perubahan fisologis dalam tubuh perempuan yang terjadi secara berkala dan dipengaruhi oleh banyak faktor, Kusmiran (2011) mengatakan mengenai faktor resiko dari variabilitas menstruasi adalah berat badan, aktiviats fisik, diet, paparan lingkungan dan kondisi kerja, gangguan endokrin, serta gangguan pendarahan. Semakin banyak faktor resiko yang dimiliki, maka kemungkinan terjadinya gangguan siklus menstruasi semakin besar.

Berdasarkan hasil penelitian, distribusi siklus menstruasi mahasiswi D3 Farmasi Tingkat 1 (Satu) Universitas Muhammadiyah Mataram, responden terbanyak memiliki siklus mentruasi normal sebanyak
24 orang $(68,7 \%), 5$ orang $(14,2 \%)$ memiliki siklus menstruasi polimenorea, dan 6 orang $(17,1 \%)$ memiliki siklus mentruasi oligemenorea.

Dalam penelitian ini penulis mencari hubungan antara tingkat stres dengan siklus mesntruasi dengan menggunakan uji chi-square dan diperoleh hasil nilai $\mathrm{p}$ $=0,000$ yaitu $\mathrm{p}<0,05$ yang menunjukkan ada hubungan bermakna anatara tingkat stres akademik dengan siklus menstruasi.

Ada hubungan yang cukup kuat antara tingkat stres akademik dengan siklus menstruasi mahasiswi tingkat 1 (satu) Farmasi Universitas Muhammadiyah Mataram. Hal ini dibuktikan dari besarnya nilai korelasi $\mathrm{r}=$ o,760 menunjukkan adanya kekuatan korelasi yang yang sangat kuat antara tingkat stres dengan siklus menstruasi responden. Nilai koefesien korelasi yang positif menunjukkan arah korelasi yang positif. Korelasi ini menunjukkan semakin tinggi tingkat stres responden maka semakin memanjang siklus menstruasinya.

Hasil penelitian ini sejalan dengan penelitian Mona, dkk (2016) di Fakultas Kesehatan Universitas Muhammadiyah Semarang Programa Studi Keperawatan yang menyatakan terdapat hubungan hubungan yang signifikan antara stres dengan siklus menstruasi, serta responden yang mengalami stres mempunyai peluang atau cenderung mengalami siklus menstruasi yang tidak teratur. Hasil tersebut pula sesuai dengan penelitian Tudoho, dkk (2014) di SMA Negeri 3 Kepulauan Tidore yang menyatakan ada hubungan antara stres psikologis dengan siklus menstruasi.

Berdasarkan hasil penelitian ditemukan pula, 20 orang $(27,4 \%)$ memiliki stres tingkat ringan dengan siklus menstruasi normal, dan 8orang (11\%) memiliki stres tingkat sedang dengan siklus menstruasi normal. Hal ini disebabkan karena siklus menstruasi tidak hanya disebabkan oleh stres saja, banyak faktor-faktor yang mempengaruhi siklus menstruasi. Hasil penelitian ini sejalan dengan penelitian Mulastin (2013) yang melakukan penelitian pada wanita pekerja diDesa Palemkerep Kecamatan Mayong Kabupaten Jepara danditemukan dari 62 responden terdapat 36 orang $(58,1 \%)$ yang mengalami stres dengan siklus menstruasi yang normal.

Prawirohardjo (2007) menyatakan saat terjadi stres maka akan terjadi respon tubuh dimana amygdala pada sistem limbik akan diaktivkan sehingga akan merangsang hipotalamus menghasilkan hormon Gonadotropin Releasing Hormon (GnRH), dimana hormon GnRH akan mensekresikan hormon FSH dan LH yang sangat berperan dalam siklus menstruasi. Bobak (2009) mengemukakan bahwa hormone FSH sangat berperan dalam proses pematangan folikel di dalam ovarium. Peningkatan hormon LH berbanding lurus dengan peningkatan kadar estrogen dan progesteron didalam tubuh. Peningkatan kadar 
estrogen akan mengakibatkan penebalan pada endometrium yang mempersiapkan terjadi ovulasi, kadar LH akan menyusut sehingga kadar estrogendan progesteron ikut menyusut dengan cepat. Seiring penyusutan kadarestrogen dan progesteron yang cepat, arteri spiral menjadi spasme, sehingga suplai darah ke endometrium fungisionel terhenti dan terjadinekrosis. Lapisan fungisional terpisah dari lapisan basal danpendarahan menstruasi dimulai. Dari penjelasan diatas, peneliti berpendapat bahwa semakin tinggitingkat stres wanita maka akan menyebabkan lonjakan hormon LH danFSH di dalam tubuhnya, yang mengakibatkan semakin berpengaruh terhadap perubahan lama menstruasi.

\section{Dampak dan Solusi Siklus Menstruasi}

a. Polimenorea

Polimenorea adalah suatu kondisi ketika seseorang wanita mengalami abnormalitas frekuensi menstruasi, yaitu siklus menstruasi kurang dari 21 hari.

1) Dampak

a) Siklus haid yang pendek (kurang dari 21 hari)

b) Frekuensi menstruasinya yang meningkat (lebih dari 1-2 kali dalam sebulan)

c) Durasi menstruasi yang panjang

d) Dapat juga disertai dengan peningkatan volume darah menstruasi.

e) Pasien dengan kondisi polimenorea dapat mengalami kondisi anemia

2) Solusi

a) Mengontrol berat badan ideal

b) Menghindari stres dan depresi

c) Menjalani pola hidup sehat dengan melakukan olahraga secara teratur dan menerapkan pola makan yang sehat.

d) Segera konsultasi ke dokter jika mengalami siklus menstruasi yang singkat (kurang dari 21 hari), untuk mencegah terjadinya komplikasi seperti anemia dan gangguan kesuburan.

e) Menjaga kesehatan genital untuk mencegah terjangkitnya penyakit menular seksual.

b. Oligomenore

Oligomenorea merupakan gangguan akibat kadar hormon yang tidak seimbang pada aksi hipotalamus - hipofisis ovarium. Kondisi ini menyebabkan siklus menstruasi memanjang yakni lebih dari 35 hari dengan jumlah perdarahan yang sama.

1) Dampak
a) Gangguan Kesuburan
b) Penyusutan payudara
c) Penyusutan kadar hormone estrogen dari dalam tubuh
d) Difesiensi hormone estrogen

2) Solusi

a) Konsumsi manakan gizi seimbang: kurangi asupan makanan asin, serta kafein. Kurangi merokok bagi yang merokok, banyak konsumsi sayuran hijau, buah, daging bebek, ikan, dan makanan bervitamin.

b) Jaga suhu tubuh tetap hangat: menjaga tubuh tetap dalam keadaan hangat dan memperlancar peredaran darah, relaksasi otot, perbanyak minum air, juga bisa mengompres perut dengan botol air yang diisi dengan air hangat selama beberapa menit dan usahakan untuk tidak menggunakan AC.

c) Perbanyak olahraga: perbanyak olahraga terutama pada saat beberapa hari sebelum datang haid sehingga saat Anda datang menstruasi tidak akan terasa sakit. Olahraga yang bisa dilakukan seperti senam yoga.

d) Perhatikan kebersihan: perhatikan kebersihan genital. Saat menstruasi berlangsung jangan melakukan hubungan badan, jangan sampai masuka angina, jangan terlalu lelah. Usahakan untuk kurangi makanan yang banyak mengandung glukosa

e) Segera konsulatsi kedokter untuk mencegah terjadinya hal yang tidak diinginkan.

\section{SIMPULAN DAN SARAN}

1. Simpulan

Berdasarkan hasil penelitian pada mahasiswi dapat disimpulkan bahwa ada hubungan antara tingkat stres dengan siklus menstruasi mahasiswi D3 Farmasi Tingkat 1 (Satu) Universitas Muhammadiyah Mataram ( $\mathrm{p}=$ o,000; $p<0,005$ denganbesarkorelasi $r=0,760$

2. Saran

a. Bagi peneliti selanjutnya diharapkan dapat menjadi pertimbanganmasukan dalam penelitian selanjutnya yang meneliti tentang stres, baik itu kaitannya dengan pola siklus menstruasi maupun dengan yanglainnya.

b. Penelitian ini memiliki keterbatasan yang hendaknya diperbaiki untuk penelitian selanjutnya, yaitu penelitian ini masih belum dapat mengontrol seluruh variabel perancu yang dapat mempengaruhi variabel yang diteliti.

\section{DAFTAR RUJUKAN}

[1] Anamika, S., Devender, T., Pragya, S., Renuka, S., 2008. Problems Related to Menstruation and Their Effect on Daily Routine Of Students Of A Medical College in Delhi, India. Asia Pac J Pub Health. 20(3):234-41. 
[2] Dorlan, W.A. Newman, 2000, Kamus Kedokteran Dorland, Alih Bahasa Huriwati Hartatnto, dkk.,edisi 29, EGC, Jakarta

[3] Hestiantoro,A.2007.Mengapa Haid Tidak teratur? Penyebab dan solusinya. http://www.unhas.ac.id// Manajemen. Diakses tanggal 5 juni.

[4] Kusmiran, E. 2011. Kesehatan Reproduksi Remaja Dan Wanita. Jakarta: Salemba Medika.

[5] Owen, S. (2005). Limit Order Trading Behavior And Individual Investor Performance. The Journal Of Behavioral Finance, 6 (2), 71-89.

[6] Sriati A. Tinjauan Tentang Stres. 2007. Available fromhttp://resources.unpad.ac.id/unpadcontent/uploads/ publikasi_dosen/TINJAUAN\%20TENTANG\%20STRES.p df

[7] Winkjosastro, H., (2005). Ilmu Kandungan. Yayasan Bina Pustaka Sarwono Prawiroharjo: Jakarta

[8] Wiknjosastro, Hanifa. 2012. Ilmu Kandungan. Jakarta: Yayasan Bina Pustaka Sarwono Prawirohardjo

\section{PROFIL PENULIS UTAMA}

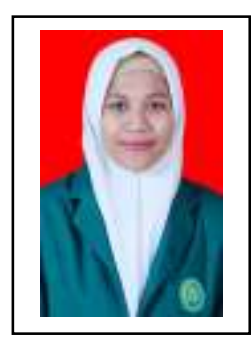

Nama : Ika Nurmala Sari

TTL : Kerongkong, 11 Juli 1998

Agama : Islam

Email : ikans@gmail.com

Riwayat Pendidikan

1. SDN 1 KERONGKONG

2. SMPN 3 SELONG

3. SMAN 1 SUKAMULIA 